\title{
Cascaded H-Bridge Inverter for Wind Driven Isolated Squirrel Cage Induction Generators
}

\author{
G. Manohar ${ }^{1}$ and K. Chiranjeevi ${ }^{2}$ \\ ${ }^{1}$ Assoc. Professor, CVR College of Engineering/EEE Department, Hyderabad, India \\ E mail: manohar.gangikunta@gmail.com \\ ${ }^{2}$ PG Scholar, CVR College of Engineering/ EEE Department, Hyderabad, India \\ E mail: chiru.maheshwaram.019@gmail.com
}

\begin{abstract}
This paper describes the simulation and harmonics analysis of cascaded five-level $\mathbf{H}$-bridge inverters fed induction motor load drive for islanding mode applications. The self - excited induction generator (SEIG) fed H-bridge Multi-Level Inverter (MLI) for wind energy conversion systems is chosen for several islanding mode applications. In this paper, the SEIG (for standalone systems) fed cascaded five level inverter for induction motor load applications are clearly explained with the help of MATLAB / SIMULINK models. The generated voltage of the wind driven SEIG is mainly depending on the wind velocity fluctuations and appropriate load conditions. The five level cascaded inverters have interface with the wind driven SEIG. By choosing appropriate value of Modulation Index (MI), the variable voltage and variable frequency of the generator can be finely controlled. The simulation and harmonic analysis of the proposed inverter will be discussed, and the total harmonic distortion of stator current for different modulation index at different switching frequencies are evaluated and the speed and torque of induction motor for different load torques are plotted.
\end{abstract}

Index Terms: Self - Excited Induction Generator (SEIG), Variable speed Wind Turbine, Multi Level Inverter (MLI), Induction Motor (IM), Modulation Index (MI).

\section{INTRODUCTION}

Wind energy conversion scheme the use of a wind turbine driven SEIG, modern electricity virtual converter was modelled, analysed and completed. Generation of electrical energy from the wind the wind energy is gaining tremendous importance internationally in this decade. Modern variable frequency drives operate with the aid of changing a 3-phase voltage deliver to DC the usage of out of control rectifier. The values of capacitance required for self-excitation were analysed formerly [1]- [2]. Especially in far flung areas, Self-Excited Induction Generators are generating proper energy in comparison with specific generators. Employing static power electronic converters, the variable voltage and variable frequency of the SEIG is converted into desired voltage and standard frequency. The wind turbines employed in wind generation system have strong production, lower inertia, and run-time charge, a good deal much less preservation fee and better short universal performance.

If the capacitance is insufficient, the induction generators will not be able to construct the voltage. In order to build up the terminal voltage, a constant speed wind turbine tied induction generator requires reactor power support which is generally provided by capacitor banks of large capacity. Wind turbines are produced in a wide scope of vertical and level pivot. Less capacity wind turbines are utilized for simple applications, such as battery charging for power traffic cautioning signs.

Turbines with moderate capacity can be exploited for making assurances to a domestic power supply while vending extra energy back to the utility provider through the electrical network. Wind turbines with a capacity of 5MW per unit are available in and used by the utilities today. Wind turbines can either can be coupled to SEIG or Doubly Fed Induction Generator (DFIG). Requirement of reactive power for building the terminal voltage is major limitation of constant speed induction generators.

\section{Proposed System Description}

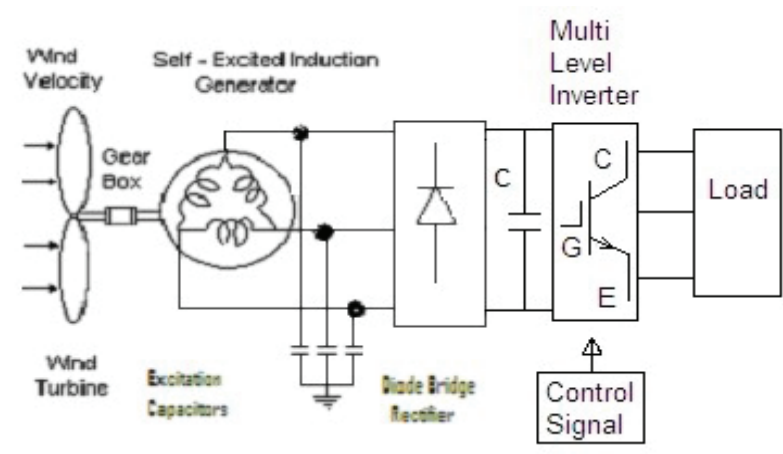

Figure 1. Proposed Impedance Source Inverter based Wind Power Generation System.

The proposed impedance source inverter-based wind energy driven SEIG encouraged burden is shown in the "Fig. 1,". The SEIG is driven by the wind turbine and output of the induction generator is fed to five-level cascaded $\mathrm{H}$ bridge inverter which in turn provides the terminal voltage to induction motor. The power transformation proficiency of ZSI is improved in contrast with the conventional inverters for wind electric power application. The desired reactive power of the SEIG is provided by the three-phase capacitor banks connected at the output terminals of the SEIG. The variable yield voltage from the acceptance generator is amended and after that modified by utilizing the proposed 
inverter. The ZSI can be made to operate to deliver output voltage greater than the voltage fed to it by effectively controlling the shoot through time. Overall power factor of the system can be improved by the proposed method with an additional benefit of reduced Total Harmonic Distortion (THD) in the stator current.

\section{A. Wind Turbine Equations and characteristics}

Due to simple construction and working principle, a horizontal axis wind turbine is preferred in wind energy systems and it will produce electric power economically. The wind turbine rotor drives the induction generator through a step-up gear box.

The mechnical power output of wind turbine is given by

$$
\mathrm{P}_{\mathrm{W}}=0.5 \rho \mathrm{CpAVw}
$$

where $\mathrm{A}$ is the area in sq. meters

$\mathrm{V}_{\mathrm{W}}$ is the Velocity of the wind in $\mathrm{m} / \mathrm{s}$ $\mathrm{Cp}$ is power co efficient and is expressed as a function of $\lambda$

$$
\begin{gathered}
\lambda=\mathrm{R} \omega_{t} / \mathrm{V}_{\mathrm{W}} \\
\mathrm{C}_{\mathrm{P}}=0.5\left(\left(116 / \lambda_{1}\right)-0.4 \beta-5\right) \mathrm{e}-{ }^{16.5 / \lambda 1}
\end{gathered}
$$

where $V_{w}$ is the wind speed estimated on hourly basis and it's units are $\mathrm{kmph}, \mathrm{N}_{\mathrm{m}}$ is the total hours in the specified period. The maximum theoretical power co efficient is equal to 0.593 .

\section{B. Self-Excited Induction Generator Modelling}

Induction generators are broadly used, specifically polyphase induction cars that are frequently utilized in industrial drives. When the rotor of the induction machine is coupled to wind turbine and driven at a speed greater than synchronous speed, the induction machine works as induction generator generating electricity from mechanical energy. The modelling of the induction generator in $\mathrm{d}-\mathrm{q}$ axis is described by the following equation [3].

$$
\begin{aligned}
& \mathrm{pi}_{\mathrm{qs}}=-\mathrm{K}_{1} \mathrm{r}_{1} \mathrm{i}_{\mathrm{qs}}-\left(\mathrm{i}_{\mathrm{qs}} / \mathrm{Cv}_{\mathrm{ds}}+\mathrm{K}_{2} \mathrm{~L}_{\mathrm{m}} \mathrm{W}_{\mathrm{m}}\right) \mathrm{i}_{\mathrm{ds}}+\mathrm{K}_{2} \mathrm{r}_{2} \mathrm{i}_{\mathrm{qr}}- \\
& \mathrm{K}_{1} \mathrm{~L}_{\mathrm{m}} \mathrm{W}_{\mathrm{m}} \mathrm{i}_{\mathrm{dr}} \\
& \mathrm{pi}_{\mathrm{ds}}=\left(\mathrm{i}_{\mathrm{qs}} / \mathrm{Cv}_{\mathrm{ds}}+\mathrm{K}_{2} \mathrm{~L}_{\mathrm{m}} \mathrm{w}_{\mathrm{m}}\right) \mathrm{i}_{\mathrm{qs}}-\mathrm{K}_{1} \mathrm{r}_{1} \mathrm{i}_{\mathrm{ds}} \\
& +\mathrm{K}_{1} \mathrm{~L}_{\mathrm{m}} \mathrm{W}_{\mathrm{m}} \mathrm{i}_{\mathrm{qr}}+\mathrm{K}_{2} \mathrm{r}_{2} \mathrm{i}_{\mathrm{dr}}-\mathrm{K}_{1 \mathrm{Vds}} \\
& \mathrm{pi}_{\mathrm{qr}}=-\mathrm{K}_{2} \mathrm{r}_{1} \mathrm{i}_{\mathrm{qs}}+\mathrm{L}_{1} \mathrm{~K}_{2} \mathrm{~W}_{\mathrm{m}} \mathrm{i}_{\mathrm{ds}}-\left(\mathrm{r}_{2}+\mathrm{K}_{2} \mathrm{~L}_{\mathrm{m}} \mathrm{r}_{2}\right) \mathrm{L}_{2} \mathrm{i}_{\mathrm{qr}}+ \\
& \left(\mathrm{K}_{1} \mathrm{~L}_{1} \mathrm{w}_{\mathrm{m}}-\mathrm{i}_{\mathrm{qs}} / \mathrm{Cv}_{\mathrm{ds}}+\mathrm{i}_{\mathrm{dr}}\right) \\
& \mathrm{pi}_{\mathrm{dr}}=-\mathrm{L}_{1} \mathrm{~K}_{2} \mathrm{w}_{\mathrm{m}} \mathrm{i}_{\mathrm{qs}}+\mathrm{K}_{2} \mathrm{r}_{1} \mathrm{i}_{\mathrm{ds}}+\left(\mathrm{L}_{1} \mathrm{~K}_{1} \mathrm{w}_{\mathrm{m}}-\mathrm{I}_{\mathrm{qs}} / \mathrm{Cv}_{\mathrm{ds}}\right) \mathrm{i}_{\mathrm{qr}} \\
& +\left(\mathrm{r}_{2}+\mathrm{K}_{2} \mathrm{~L}_{\mathrm{m}} \mathrm{r}_{2}\right) \mathrm{L}_{2} \mathrm{i}_{\mathrm{dr}}+\mathrm{K}_{2} \mathrm{~V}_{\mathrm{ds}} \\
& \mathrm{K}_{2}=\mathrm{L}_{\mathrm{m}} /\left(\mathrm{L}_{\mathrm{s}} \mathrm{L}_{\mathrm{r}}-\mathrm{L}_{\mathrm{m}}{ }^{2}\right)
\end{aligned}
$$

\section{Induction Motor}

An induction motor is an asynchronous AC motor where power is provided to the rotating device with the useful resource of electromagnetic induction. Out of the two configurations, squirrel cage motor is extensively used in industrial and domestic applications due to its ruggedness, low maintenance cost, easy installation and superior electrical characteristics. However, in special applications where maximum starting torque is required like traction, a slip ring or wound rotor induction motor is used.

An induction motor is sometimes known as a revolving transformer due to the fact the stator (stationary element) acts as one winding of the transformer and the rotor (rotating element) is the other winding of the transformer factor.

\section{Uncontrolled Bridge Rectifier}

The output of SEIG is connected to a three-phase uncontrolled rectifier. The purpose of connecting a uncontrolled rectifier is to get a fixed DC from 3-phase AC. An ordinary low-cost diode rectifier will serve the purpose here. A series reactor connected at output terminals of the diode rectifier reduces the current ripple and a shunt capacitor reduces the ripple in the output voltage.

\section{E. Multi-Level Inverters}

Multilevel inverters are the ideal choice of industry to work with high voltages and is an attractive alternative in the area of high-power medium-voltage energy control. An inverter is a power electronic static device that converts constant DC voltage to alternating voltage preferably a sinusoidal voltage. The AC voltage may be at any desired voltage and frequency with the usage of appropriate transformers, switching, and manage circuits. Inverter don't have any transferring factors and are applied in a sizable sort of packages, from small switching power components in computers, to large modules that delivery bulk energy. The most common type of inverter which is used to generate $\mathrm{AC}$ voltage from DC Voltage is two level inverters. A two-level Inverter creates two different voltages for the load i.e. suppose we are providing $V$ as an input to a two-level inverter then it will provide $+V / 2$ and $-V / 2$ on output [4][5].

The cascaded H-bridge multi-level inverter with 5 levels is chosen in the proposed simulation. H-bridge inverter is considered for simulation since it is extensively used in applications of distributed generation with renewable sources. Especially, for integrating solar energy and wind energy roof top installations $\mathrm{H}$-bridge inverters in cascaded mode are employed.

Classification of Multilevel Inverter as shown in the "Fig. 2,". 


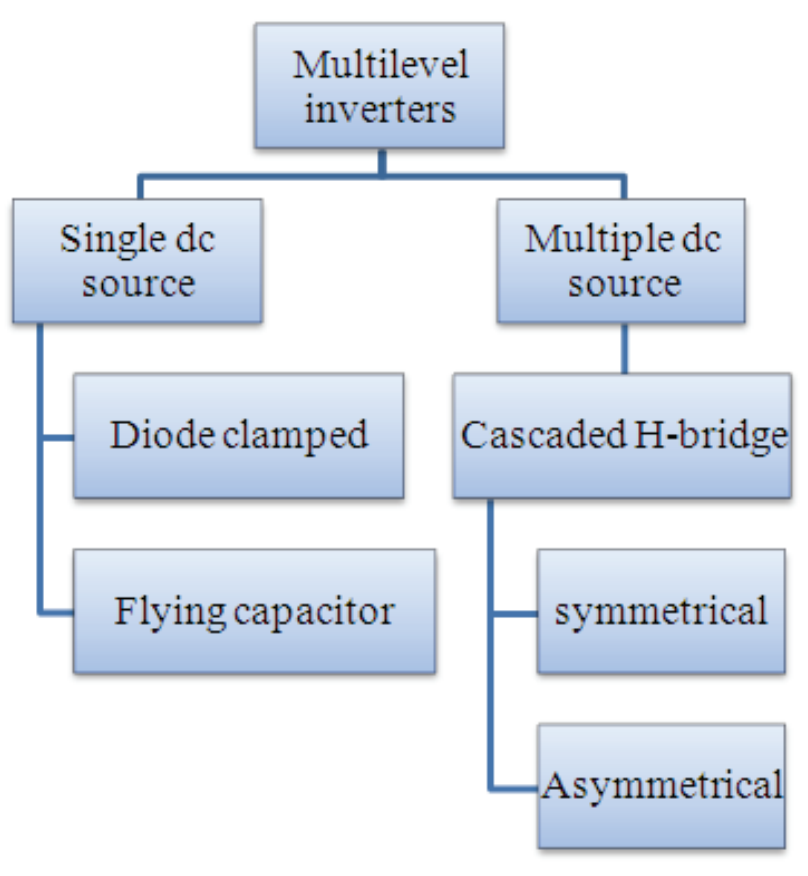

Figure 2. Classification of Multilevel Inverter

\section{Simulation RESUltS}

In this section, the wind driven Self Excited Induction Generator (SEIG) fed with five level cascaded H-Bridge inverter for wind power conversion system using Asynchronous machine as a load is simulated using MATLAB/SIMULINK [6]-[8]. By applying different loads with respect to time on asynchronous motor rotor speed and motor torque were calculated and stator current's THD analysis has been explained with the simulation results below.

"Fig. 3," shows the MATLAB/SIMULINK of proposed system comprising of a wind turbine driving an asynchronous generator. The generator output is given back to back converters with DC link in between. Here five level $\mathrm{H}$-bridge cascaded inverter is used to covert fixed DC to variable AC. This AC is used to drive an induction motor which is acting as an isolated load. "Fig. 4," shows control signal generation for single cell of $\mathrm{H}$ bridge inverter, "Fig. 5," shows the circuit diagram of a three-phase, five-level cascaded H-bridge inverter.

The Self Excited Induction (SEIG) generated 385 volts and 3-phase output voltage wave forms shown in the figure 6 , the bridge rectifier converts that $\mathrm{AC}$ power to DC power and the magnitude of the rectified voltage is 312 volts as shown in the "Fig. 7."

The multilevel inverter converts the rectified DC power to the AC power and the phase voltage is 370 volts as shown in the "Fig. 8.", line voltage of multilevel inverter is 358 volts waveforms this is shown in the "Fig. 9.", line current of multilevel inverter is 3.5 amperes as shown in the "Fig. 10,"

Different load torques are applied on Asynchronous machine at different intervals of time. Load torque versus time graph shown in the "Fig. 11,". Full load torque is considered as $26.72 \mathrm{~N}-\mathrm{m}$

Rotor speed in RPM and motor torque in N-m of asynchronous motor for different load torques at various values of modulation index are considered for simulation. Found speed of the rotor is inversely proportional to the motor torque as shown in the "Fig. 12,". From the "Fig. 12 ," rotor speed decreases by the application of load torque at different intervals. Rotor speed, asynchronous machine torque at different load torques are tabulated in in the table I.

Stator currents of asynchronous machine of all three phases viz. phase A, phase B and phase $\mathrm{C} s$ are shown in the "Fig. 13,". The magnitude of these currents at unity slip under no load conditions is very high.

Rotor currents with respect to time on rotor of asynchronous machine of all three phases viz. phase A, phase B and phase C are shown in the "Fig. 14,". Frequency of these rotor currents is high at unity slip since rotor speed is less. As the rotor speed increases, slip of the asynchronous machine decreases and hence rotor frequency decreases.

Total Harmonic Distortion (THD) of multilevel inverter output in phase A found $8.37 \%$ as shown in the "Fig. 15,".

(i) Total Harmonic Distortion (THD) of stator current of asynchronous machine in phase A with modulation index (MI) of 1.0 at switching frequency of $1050 \mathrm{~Hz}$ as shown in the "Fig. 16,".

(ii) Total Harmonic Distortion (THD) of stator current of asynchronous machine in phase $\mathrm{A}$ is shown in the "Fig. 17," The modulation index is considered as 1.0 at a switching frequency of $1550 \mathrm{~Hz}$.

(iii) Total Harmonic Distortion (THD) of stator current of asynchronous machine in phase A with modulation index (MI) of 1.0 at switching frequency of $2050 \mathrm{~Hz}$ is shown in the "Fig. 18,"and

(iv) Total Harmonic Distortion (THD) of stator current of asynchronous machine in phase A with modulation index (MI) of 1.0 at switching frequency of $3050 \mathrm{~Hz}$ is shown in the "Fig. 19,".

Total Harmonic Distortion (THD) of stator current in phase " $A$ " for Modulation Index (MI) of 1, 0.9,0.8 and 0.7 at different switching frequencies are tabulated in tables II, III, IV and V respectively.

Phase Disposition (PD) technique with multi carrier sine waves are used to generate the gate signals for $\mathrm{H}$ Bridge Inverters. Phase Opposition Disposition (POD) technique and Alternate Phase Opposition Disposition (APOD) multi carrier sine PWM techniques also can be implemented to study the behavior of asynchronous machine. Third harmonic injection pulse width modulation can also be implemented to study the behavior of the asynchronous machine for different level shifted PWM techniques discussed above. 


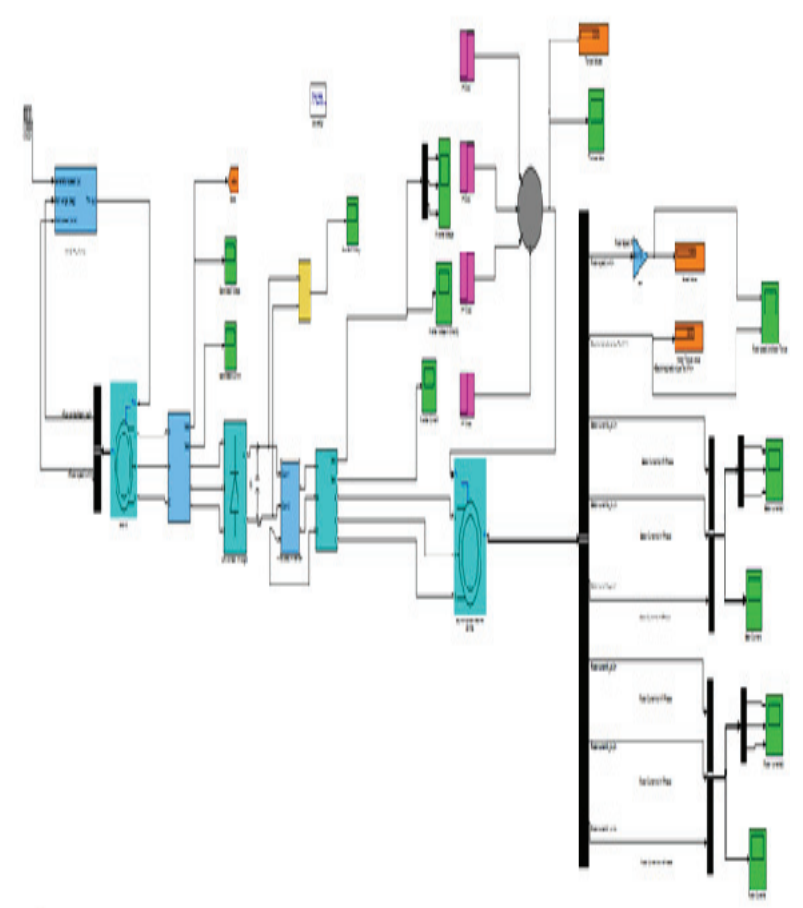

Figure 3. MATLAB/SIMLINK of proposed system.

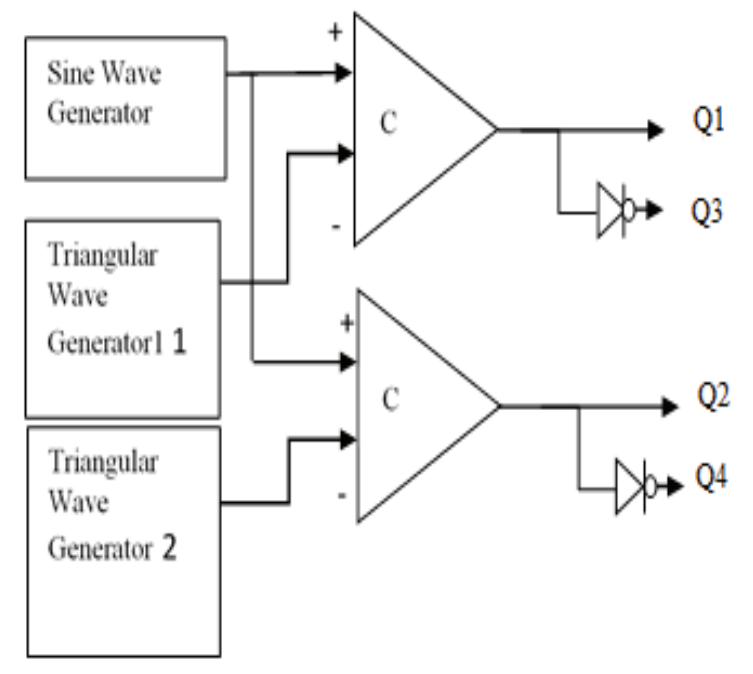

Figure 4. H-Bridge Inverter.

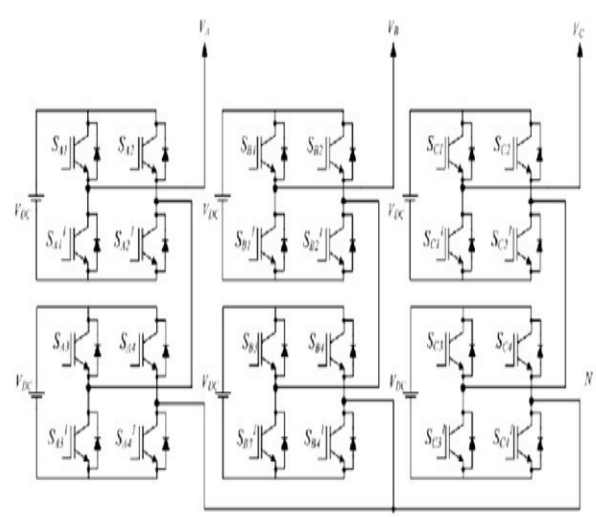

Figure 5. Three-Phase five-level cascaded H-Bridge inverter.

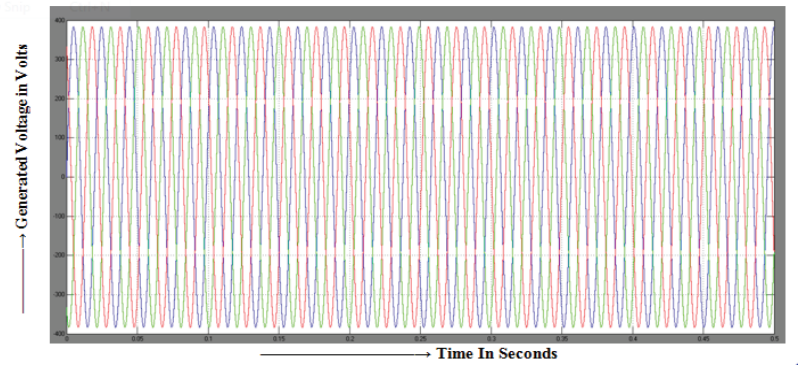

Figure 6. Self-Excited Induction (SEIG) generated voltages

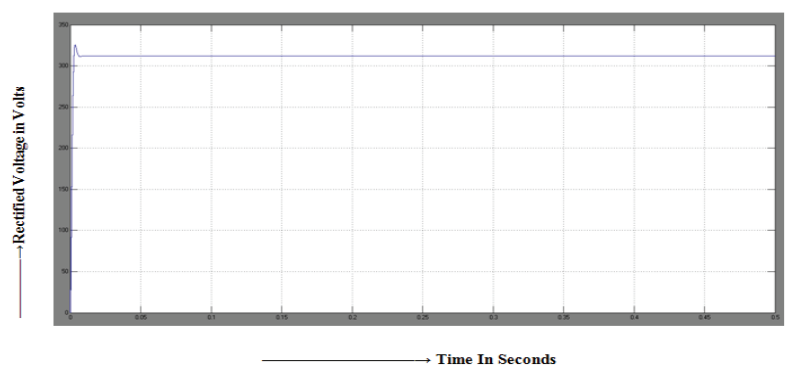

Figure 7. Rectified voltage

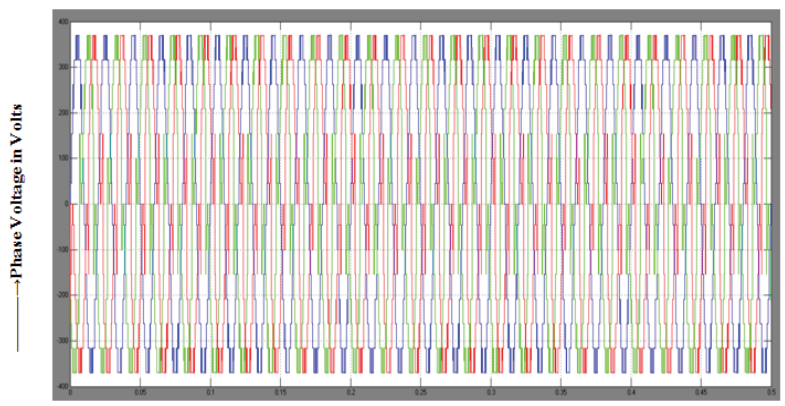

Time In Seconds

Figure 8. Multilevel Inverter output Phase voltages 


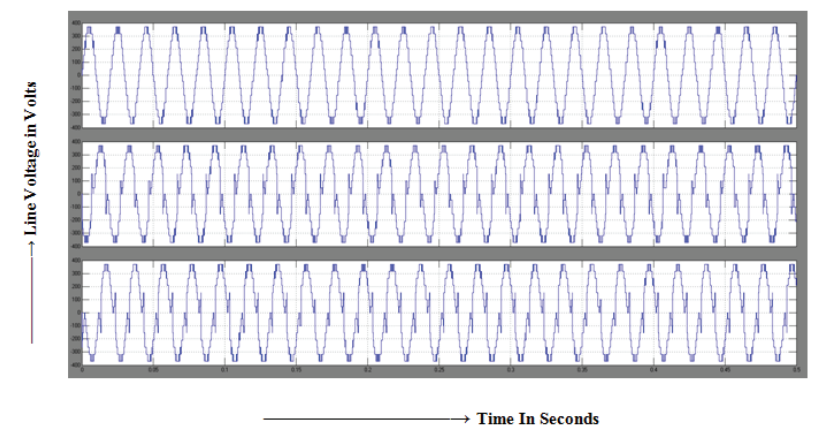

Figure 9. Multilevel Inverter output Line voltages

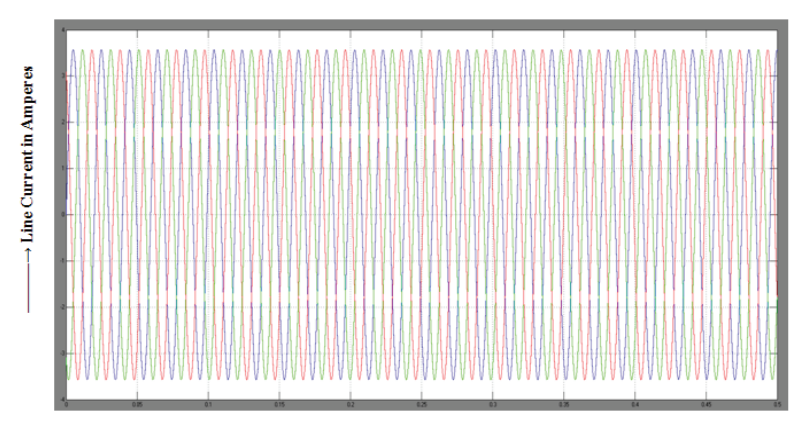

Figure 10. Multilevel Inverter output Line current

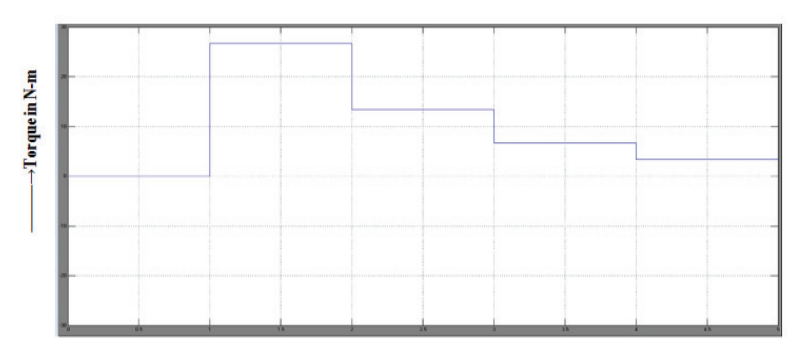

Figure 11. Applied load torque on asynchronous machine in N-m versus time in seconds.

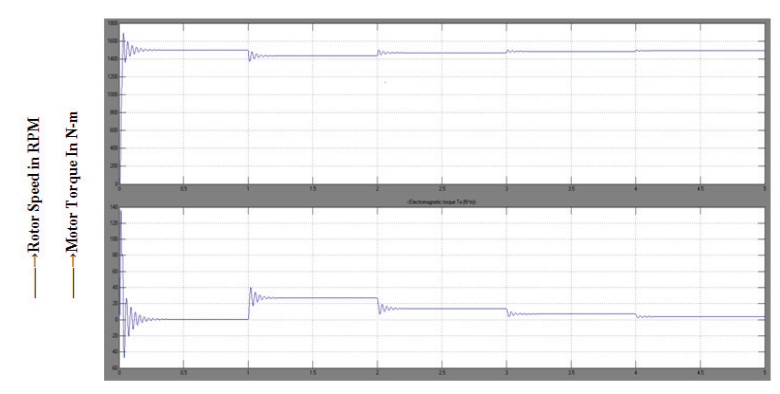

Figure 12. Rotor speed in RPM and motor torque in

$\mathrm{N}-\mathrm{m}$ of Asynchronous Machine
TABLE I.

SPEED, Motor TORques AT DiFFERENT LOAD TORQues

\begin{tabular}{|c|c|c|c|c|}
\hline $\begin{array}{c}\text { Load } \\
\text { Torque } \\
\text { setting time } \\
\text { in seconds }\end{array}$ & Load Torque & $\begin{array}{c}\text { Load } \\
\text { Torque } \\
\text { (TL)Value } \\
\text { in } \\
\text { N-m }\end{array}$ & $\begin{array}{c}\text { Motor } \\
\text { Torque } \\
\text { (Tm) } \\
\text { Value in } \\
\text { N-m }\end{array}$ & $\begin{array}{c}\text { Rotor } \\
\text { Speed } \\
\text { (N) in } \\
\text { RPM }\end{array}$ \\
\hline $\begin{array}{c}\text { TL at } 0 \\
\text { second }\end{array}$ & TL at no load & 0 & 0 & 1499 \\
\hline $\begin{array}{c}\text { TL at } 1 \\
\text { second }\end{array}$ & $\begin{array}{c}\text { TL at full } \\
\text { load }\end{array}$ & 26.72 & 27.16 & 1435 \\
\hline $\begin{array}{c}\text { TL at } 2 \\
\text { seconds }\end{array}$ & $\begin{array}{c}\text { TL at half } \\
\text { full load }\end{array}$ & 13.36 & 13.8 & 1468 \\
\hline $\begin{array}{c}\text { TL at } 3 \\
\text { seconds }\end{array}$ & $\begin{array}{c}\text { TL at quarter } \\
\text { full load }\end{array}$ & 6.68 & 7.1 & 1484 \\
\hline $\begin{array}{c}\text { TL at } 4 \\
\text { seconds }\end{array}$ & $\begin{array}{c}\text { TL at octa } \\
\text { full load }\end{array}$ & 3.34 & 3.8 & 1491 \\
\hline
\end{tabular}

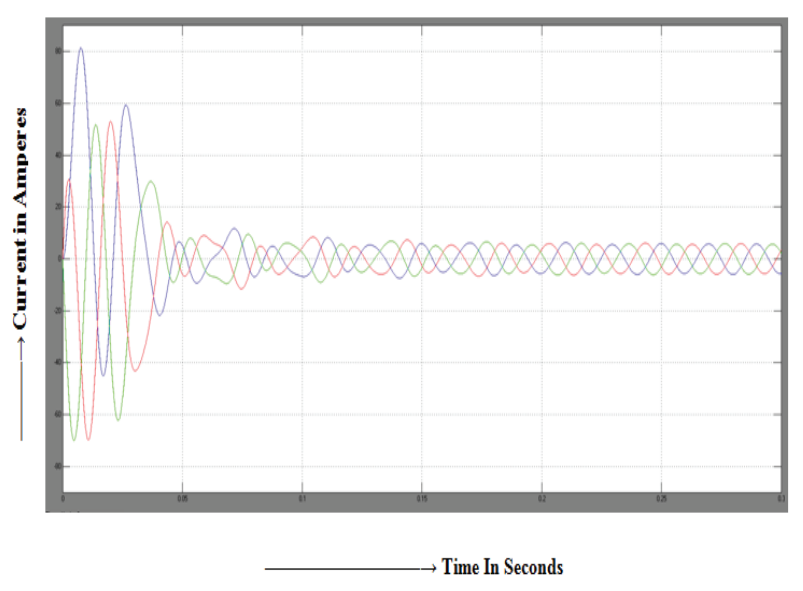

Figure 13. Stator currents of asynchronous machine w.r.t. time.

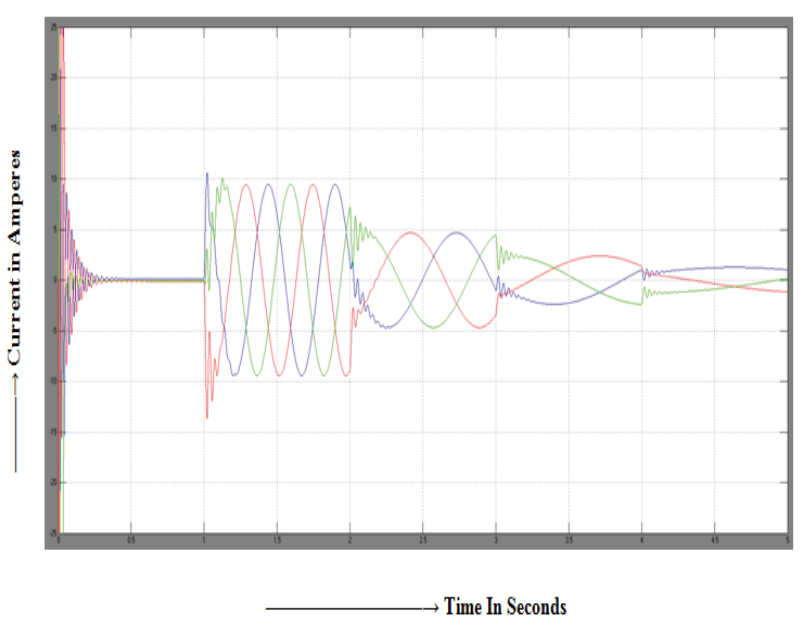

Figure 14. Rotor currents of asynchronous machine w.r.t. time. 


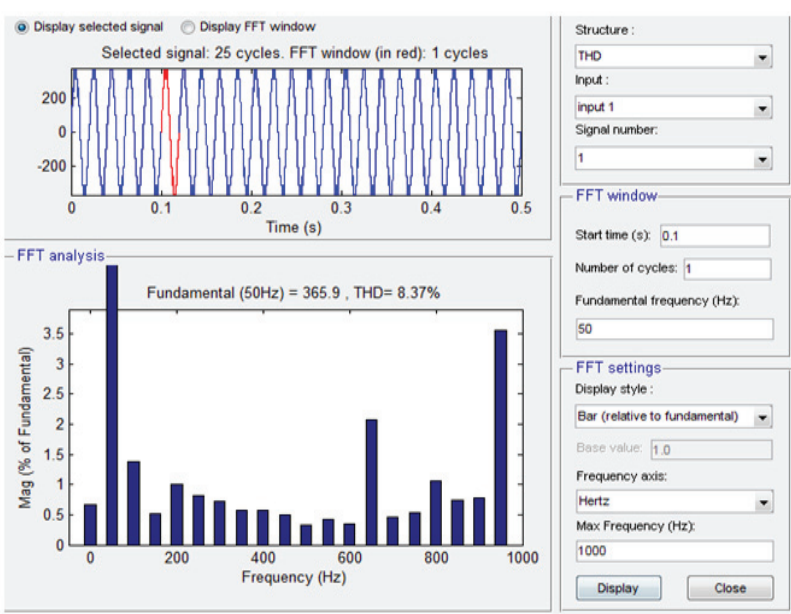

Figure 15. THD analysis of multilevel inverter output.

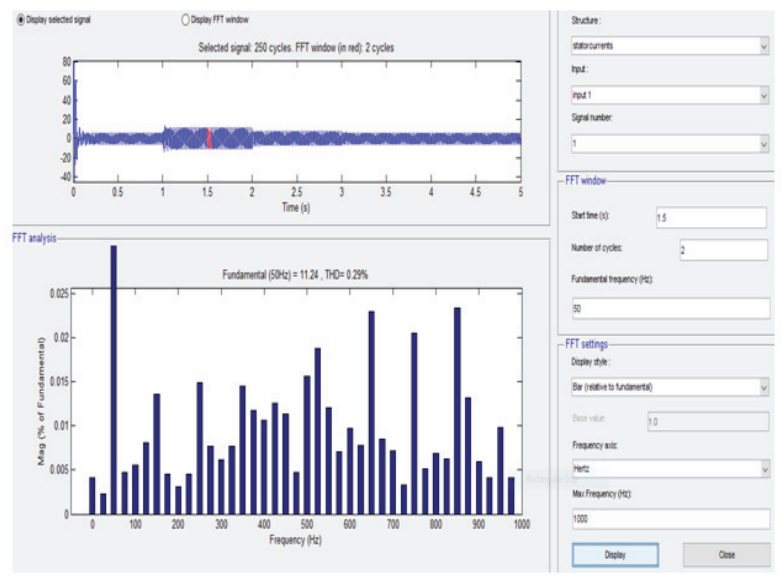

Figure 16. THD analysis of stator current of asynchronous machine in phase $\mathrm{A}$ at Modulation Index $=1$

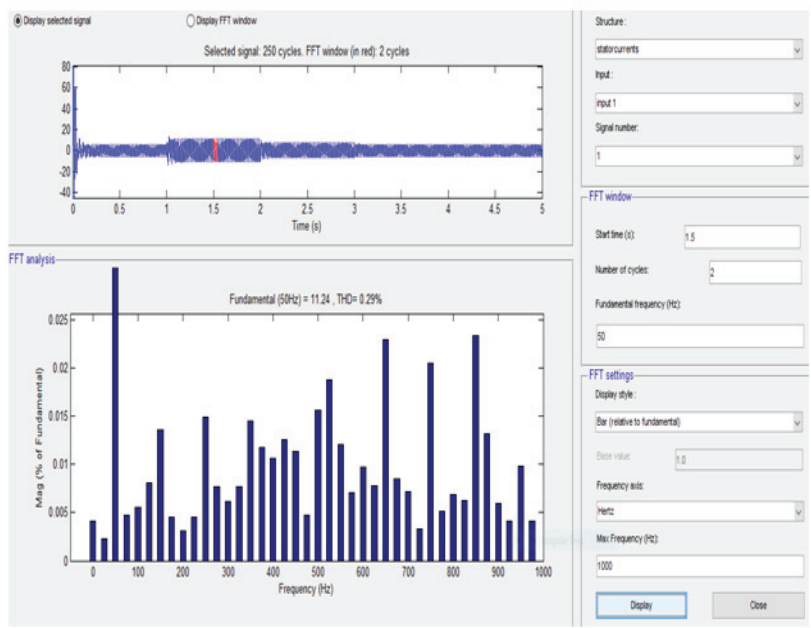

Figure 17. THD analysis of stator current of asynchronous machine in phase A at Modulation Index $=0.9$

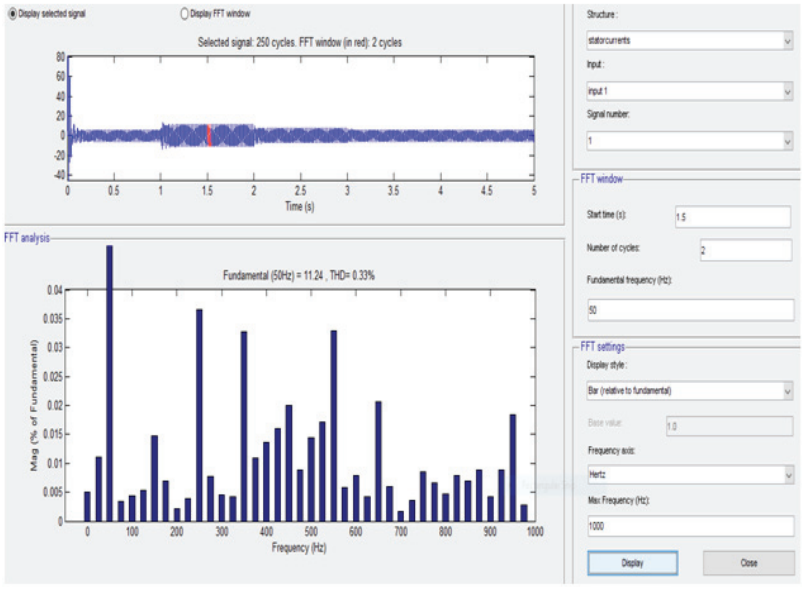

Figure 18. THD analysis of stator current of asynchronous machine in phase $\mathrm{A}$ at Modulation Index $=0.8$

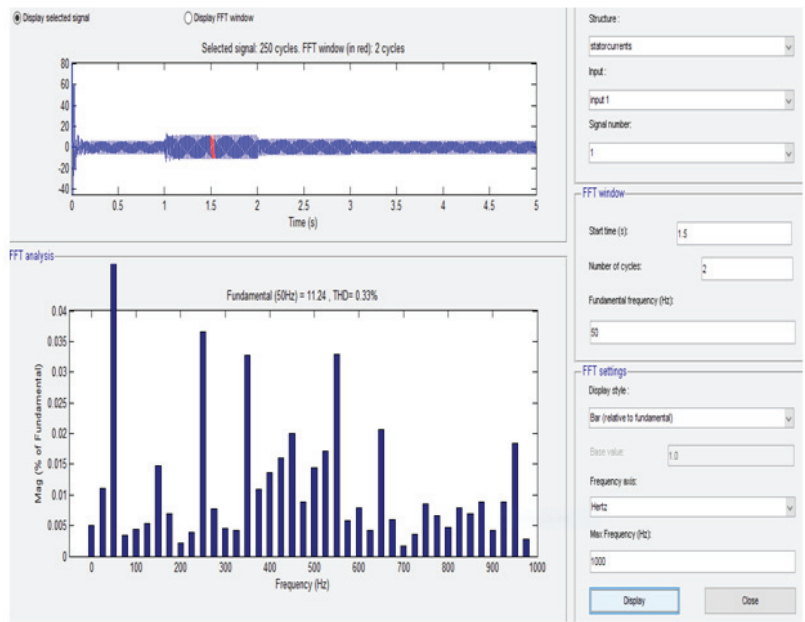

Figure 19. THD analysis of stator current of asynchronous machine in phase $\mathrm{A}$ at Modulation Index $=0.7$

TABLE II.

THD ANALYSIS of StATOR CURRENT IN PHASE A AT MODULATION INDEX $(\mathrm{MI}=1)$

\begin{tabular}{|c|c|}
\hline Ts & THD of Stator Current in Phase A \\
\hline 1050 & $0.29 \%$ \\
\hline 1550 & $0.29 \%$ \\
\hline 2050 & $0.33 \%$ \\
\hline 3050 & $0.33 \%$ \\
\hline
\end{tabular}

TABLE III.

THD ANALYSIS OF STATOR CURRENT IN PHASE A AT MODUlation INDEX $(\mathrm{MI}=0.9)$

\begin{tabular}{|c|c|}
\hline Ts & THD of Stator Current in Phase A \\
\hline 1050 & $0.34 \%$ \\
\hline 1550 & $0.32 \%$ \\
\hline 2050 & $0.32 \%$ \\
\hline 3050 & $0.34 \%$ \\
\hline
\end{tabular}


TABLE IV.

THD ANALYSIS OF STATOR CURRENT IN PHASE A AT MODULATION INDEX $(\mathrm{MI}=0.8)$

\begin{tabular}{|c|c|}
\hline Ts & THD of Stator Current in Phase A \\
\hline 1050 & $0.36 \%$ \\
\hline 1550 & $0.33 \%$ \\
\hline 2050 & $0.33 \%$ \\
\hline 3050 & $0.36 \%$ \\
\hline
\end{tabular}

TABLE V.

THD ANALysis of Stator CurRENT IN PHASE A AT Modulation IndeX $\mathrm{MI}=0.7)$

\begin{tabular}{|c|c|}
\hline Ts & THD of Stator Current in Phase A \\
\hline 1050 & $0.37 \%$ \\
\hline 1550 & $0.32 \%$ \\
\hline 2050 & $0.33 \%$ \\
\hline 3050 & $0.37 \%$ \\
\hline
\end{tabular}

\section{CONCLUSIONS}

The cascaded five level $\mathrm{H}$ - bridge inverter fed wind driven self-excited induction generator has been simulated and waveforms of the load (Induction motor) are observed. The multi-level inverter fed drive reduces the harmonic contents in comparison with the conventional inverter fed structures. Load torque applied on asynchronous machine with respect to time at different loads, rotor speed and motor torque observed at this respective load torques applied on this asynchronous machine. Stator currents and rotor currents are obtained with respective to load torque and time interval. Total Harmonic Distortion (THD), calculated for stator current of asynchronous machine for different modulation indexes was found to be very less and the waveforms are almost sinusoidal in nature. THD was also calculated for different switching frequencies and found that that THD decrease with increased switching frequencies.

\section{REFERENCES}

[1] Ahmed, Tarek, Osamu Noro, K. Matzuo, Yuji Shindo, and Mutsuo Nakaoka. "Minimum excitation capacitance requirements for wind turbine coupled stand-alone self-excited induction generator with voltage regulation based on SVC." In The 25th International Telecommunications Energy Conference, 2003. INTELEC'03., pp. 396-403. IEEE, 2003.

[2] Anagreh, Yaser. "Steady state performance of series DC motor powered by wind driven self-excited induction generator." Proceedings on Rev. Energ. Ren: power Engineering, pp 9-15,2001.

[3] Slootweg, J. G., Henk Polinder, and Wil L. Kling. "Dynamic modelling of a wind turbine with doubly fed induction generator." In 2001 Power Engineering Society Summer Meeting. Conference Proceedings (Cat. No. 01CH37262), vol. 1, pp. 644-649. IEEE, 2001.

[4] Manohar, G., and S. Venkateshwarlu. "Performance Analysis of Three Level Diode Clamped Inverter fed Induction Machine using Multicarrier PWM Techniques." CVR Journal of Science and Technology 16, no. 1 ,pp.59-65,2019

[5] Daher, Sergio, Jürgen Schmid, and Fernando LM Antunes. "Multilevel inverter topologies for stand-alone PV systems." IEEE transactions on industrial electronics 55, no. 7 ,pp. 2703-2712, 2008
[6] Kasera, Jitendra, Ankit Chaplot, and Jai Kumar Maherchandani. "Modeling and simulation of wind-PV hybrid power system using Matlab/Simulink." In 2012 IEEE Students' Conference on Electrical, Electronics and Computer Science, pp. 1-4. IEEE, 2012.

[7] Soetedjo, Aryuanto, Abraham Lomi, and Widodo Puji Mulayanto. "Modeling of wind energy system with MPPT control." In Proceedings of the 2011 International Conference on Electrical Engineering and Informatics, pp. 1-6. IEEE, 2011.

[8] Manohar, G., and S. Venkateshwarlu. " Analysis of Grid Connected Doubly Fed Induction Generator based Wind Turbine." CVR Journal of Science and Technology,vol. 10 ,pp.59-64, June 2016. 